\title{
Digital Technologies in Activities of Russian Courts: Prospects of Artificial Intelligence Application
}

\author{
Dneprovskaya M.A. ${ }^{* *}$ Abramitov S.A. ${ }^{1}$

\begin{abstract}
Institute of Economics, Management and Law, Irkutsk National Research Technical University, Irkutsk 664074, Russia
\end{abstract} \\ *Corresponding author. Email: mariosky@ rambler.ru
}

\begin{abstract}
In the present study, the authors point out the importance of the use of digital technologies in the distribution of justice, as it greatly simplifies judicial activities by saving labour and time resources. Attention is paid to the fact that in the conditions of action of e-justice elements, providing the possibility of electronic document circulation between the court and participants of the proceedings, it becomes actual and necessary to introduce technological solutions based on artificial intelligence, such as computer programs. The authors consider the prospects of application of computer programs based on artificial intelligence in the activities of courts, as well as some problems of their implementation. The authors believe that in the distribution of justice in a summary and ordered procedure in which the requirements are undisputed (for example, in cases of collection of mandatory payments), i.e. in "standard" cases on the basis of documents submitted to the court, it is possible to use a computer program based on artificial intelligence, which will be able to analyze the situation, assess the validity of the requirement and the documents submitted, determine the applicable law and offer the judge possible options of solutions without sessions of the court and summons to court. Thus, a computer program based on artificial intelligence will be able to technically develop options for a court ruling, and the judge will either approve it or not. The authors suppose that in this case the electronic judge will not completely replace a human judge in the distribution of justice, but will only provide technical assistance. The use of such digital technology in the ruling of the court will be auxiliary in nature.
\end{abstract}

Keywords: digital technologies, information technologies, e-justice, artificial intelligence, Russian justice,

electronic judge

\section{INTRODUCTION}

In modern Russia, a course has been chosen towards the informatization of public administration within the framework of the development of the digital economy. Digital technologies have been introduced in various fields of action, including activities related to the distribution of justice. Taking into account the workload of judges and court staff, the optimization of their activities is necessary. It requires the introduction of computer programs based on artificial intelligence, capable of analyzing a large amount of data and developing draft court decisions, taking over the execution of some actions performed by the judge, which are already beginning to be applied in the judicial practice of some states, known as e-justice, e-judge. The main task of such systems is the analysis of data using artificial intelligence with a view to assign simple routine work to the electronic judge in order to free the time of human judges and court staff to perform other functions. It seems relevant to consider factors that determine the need to create such software solutions; categories of cases on which it is possible to render judicial decision with use of the electronic assistant on the basis of an artificial intellect; the problems of introducing artificial intelligence technologies in the distribution of justice.

\section{RESEARCH METHODS}

The research methods are: general scientific (systematic, logical) and private scientific (formal and legal).

\section{RESULTS AND DISCUSSION}

Digital technologies are increasingly penetrating the sphere of judicial activity in modern Russia. Specialists in the humanities, including legal and technical sciences, conduct scientific research with a view to optimizing judicial activity using digital technologies. The result of such research was the introduction of various software and hardware complexes into the activity of the courts, ensuring the conduct of judicial proceedings, electronic recording of the results and the progress of the legal proceedings carried out by the court and other participants of the proceedings (for example, the State Automated System "Justice", complex of automated information systems of arbitration courts, including the automated information system "Court Proceedings", software 
complex "Judicial Arbitration Clerical Work", information systems "My Arbitrator", "Commercial Case File", "Bank of Arbitration Court Decisions" and other software products to ensure the organization of electronic document flow within the court and in communication with people involved in the case, maintaining the electronic archive of court cases, creating and supporting the current status of the official website of the judicial authority, organization of video conferencing with the court, audio recording of court sessions and court reporting.

Currently, Russia has a National Strategy for the Development of Artificial Intelligence for the period up to 2030, approved by the Decree of the President of the Russian Federation from October 10, 2019 № 490 "On the development of artificial intelligence in the Russian Federation", which defines the purposes and main objectives of the development of artificial intelligence, as well as measures aimed at its use [1]. As one of the directions of development and use of artificial intelligence technologies in the strategy is named the improvement of quality of public services, as well as reducing costs for their provision.

It seems that the introduction of e-justice elements in the activity of courts related to technological solutions and computer programs based on artificial intelligence with an appropriate level of technical equipment, as well as knowledge and skills in this area will significantly reduce labour and time resources in the acceptance of documents in electronic form, their registration, processing, storage, transfer and other actions, and perhaps even in the adoption of procedural decisions based on the analysis of information received.

Numerous scientific publications have been devoted to the use of digital technologies based on artificial intelligence, which are able to perform functions previously peculiar only to humans [2-6].

The currently level of development of digital technologies allows in the long term to introduce technological solutions and computer programs based on artificial intelligence in the activities of courts. In particular, in the near future, a computer program based on artificial intelligence will be available in Russian courts for automated preparation of court transcripts based on speech recognition system [7]. Malko A.V., Kostenko M.A. believe that it is possible to introduce into the judicial activity the program "Electronic Judge", which, in the first stage, can be developed to handle relatively simple categories of court cases (e.g. cases of administrative traffic offences, cases considered in summary or special proceedings) [8].

According to Kapustin O. A., administrative proceedings on recognition of information placed in data telecommunications network, including the Internet, as information the distribution of which is prohibited in the Russian Federation, could be carried out in electronic form [9].

The Judge of the Supreme Court of the Russian Federation $\mathrm{V}$. Momotov noted that at present it is at least premature to talk about replacing a judge with artificial intelligence, and most likely it is impossible, however, he believes it is possible to use artificial intelligence when considering indisputable requirements, when the work of a judge is not connected with the analysis of legal regulations between the parties and is of technical nature, but even in that case the final decision should be made by a person [10].

According to Gritsay O. V. and Gubina E. N., it is impossible to entrust the functions of justice directly to any robotic system, since this would violate such a principle of judicial procedure as immediacy, when it is the court that evaluates the evidence, determines what circumstances which are relevant for the consideration of the case are established and what circumstances are not established, what are the legal regulations between the parties, what law should be applied in this case and whether the claim is subject to satisfaction. They note that at present, most scientists and practitioners are opposed to allowing artificial intelligence programs to the distribution of justice [11].

A number of researchers expressed misgivings about the automatization and widespread digitalization of the distribution of justice. In opinion of Zakirov R.F., transfer of functions of the judge to the computer program based on artificial intelligence will lead to risk of disbalance between law and justice, since artificial intelligence, with all its advantages, is inferior to natural intelligence that can sense and perceive the received information [12].

Popova I.P. also claims that a robot cannot replace a judge, because there is a great danger of formalization and patternization of thinking in decision-making, as well as the danger of simplification of the distribution of justice [13].

Kleandrov M. I. points out that in the foreseeable future the transfer of the function of justice to an electronic judge will not occur and gives the following arguments: a human judge has a set of moral and other qualities, one of which is the idea of justice, which cannot be programmed for electronic judge; justice itself is irrational and cannot be formalized and programmed for a robot. In addition, he draws attention to the fact that there is a legislative requirement to perform judicial acts on the basis of the principle of justice, and if justice is unfair, it is not justice [14].

Branovitsky K. L., sharing apprehension about the risks of mechanical justice, notes that in the Russian civilised process "mechanization" through the simplification of proceedings has long taken place, since more than half of civil proceedings in the courts of general jurisdiction and arbitration courts are heard without summoning the parties and holding court sessions (ordered and summary proceedings) [15].

According to the data of the Judicial Department under the Supreme Court of the Russian Federation, in the first half of 2019, the judges heard (completed) 10274155 civil and administrative cases in accordance with the Civil Procedural Code of the Russian Federation (CPC RF) and the Code of Administrative Proceedings of the Russian Federation (CAC RF), including 8184857 cases with rendering of judicial decisions. In turn, completed with rendering of judicial decisions: administrative cases on 
recovery of mandatory payments and sanctions - 1494889; civil cases - 6689968 [16].

Taking into account the huge amount of work and burden on judges in limited terms, the routine work of judges and court staff can be optimized by creating appropriate software systems (programs, algorithms). It seems necessary to develop a program of "electronic judge", which could form a pattern of a decision on a simple category of civil and administrative cases, where there is no issue on law, and is only indicated, for example, the name of the debtor, his place of residence, the amount of debt on obligatory payments and sanctions, enforced by means of a judicial order, having the force of an executive document (Chapter 11 of the Civil Procedural Code of the Russian Federation) or other decisions in a summary procedure (Chapter 33 of the Code of Administrative Procedure of the Russian Federation) or the like. If the corresponding information is manually entered into the program traditional way or it is received in electronic format, which will minimize the risk of technical errors in the documents, the result will be a certain procedural decision, which the judge will verify and approve with his signature. Such a computer program will significantly free up the judge and the court personnel, by automating some of the functions related to procedural activities in the distribution of justice. However, in turn, they will be required to know this program and have new professional competences in its use.

It is necessary to distinguish between programs that are based on the application of artificial intelligence and conventional programs that automate any actions. For example, automatic sorting of legal documents or distribution of load on judges (choice of arbitrators) are the results of ordinary computer programs, in turn, artificial intelligence technologies assume a certain level of intelligence, which is compared to the thinking or behaviour of a person [17].

Chernykh I. I. believes that during the consideration of civil cases the assessment of indirect evidence can be submitted to algorithmization, since the court compares indirect evidence with the sought legal fact in the case, determining the nature of their relationship with each other. Artificial intelligence could reveal the relationship of each of the indirect evidence collected in the case to a legally relevant circumstance by determining the number of coincidences about the alleged connection, given that it is of probabilistic nature [18].

If the program only automates the actions, ensuring the speed of their production, without interfering with the matter of decisions where the prerogative should be in the hands of a human judge, it will benefit justice. It is probably difficult to catch a fine line of how far artificial intelligence is allowed to make significant decisions, but it is possible if we weigh up all the risks of such interference, distinguishing between ordinary algorithms (programs) and programs based on artificial intelligence, imitating human natural thinking.

Amiyants K.A., Chemerinsky K.V. believe that using of artificial intelligence in the distribution of justice should be "auxiliary" rather than "defining" in order to optimize the routine component of justice [19].

Rostovschikov I.V., Aleshkova I.A. Molokaeva O.K. do not rule out the possibility of introducing artificial intelligence into judicial activity, having fixed the principle of proportionate integration of the artificial intelligence and analytical human mind in administration of justice [20].

The development of digital technologies will inevitably lead to the participation of electronic judge (program based on artificial intelligence) at certain stages of the proceedings in order to optimize judicial activity, since some necessary legal and material and technical conditions have already been created. However, when deciding on the transfer of some of the functions of a judge to program decisions, it is necessary to determine at what stage of the proceedings this is possible; in what category of cases; what volume of the judge actions can be transferred; what information can be transferred to processing and to what extent; whether to provide the human judge with an assessment of the quality of the taken decision and the opportunity to disagree with it or not, and so on. The introduction of artificial intelligence into the distribution of justice must be done with care, foreseeing the level of decision-making intelligence that electronic judge will provide, as well as evaluating the advantages of such technologies and possible risks.

In our opinion, when it comes to the use of technological solutions based on artificial intelligence in the activities of courts, we are talking about the use of analytical tools that allow predicting future decisions in a particular case, based on the analysis of several similar cases. Therefore, many authors rightly believe that the use of artificial intelligence in the distribution of justice should not be determinative but supportive.

It seems that a promising direction is the development of a computer program based on artificial intelligence, which will be able to analyze disputable situations, to identify possible options for the application of the law, to offer possible solutions, for example, in cases where the facts are indisputable, the applicable law is obvious, similar typical cases are known. As a result, the program can diagnose the situation and develop a draft conclusion for its consideration by the judge, which can be useful when considering the same type of "standard" cases.

One of the potential directions of application of computer programs based on artificial intelligence is the automated development of decisions when considering cases in a summary and ordered procedure, when a court decision is made without holding court hearings, without summons to court, based on documents submitted to the court that reflect the essence of the requirement. 
[4] T.S. Nikiforova, K.M. Smirnova, Will Robots

\section{CONCLUSION}

The automation of judicial activity using innovative digital technologies is necessary and important. Computer programs based on artificial intelligence, with their competent use and the appropriate level of technical equipment of courts, can greatly facilitate access to judicial protection. With the appropriate level of material and technical resources and legal culture, it becomes possible to use programs that simplify the technical work of judges and court staff, where significant intellectual efforts are not required, as well as programs such as "electronic judge", which enable the drafting of court decisions for judges based on artificial intelligence.

Artificial intelligence helps to improve the efficiency of judicial activity, but it is necessary to overcome the inertia of thinking and stereotypes in relation to the introduction of digital technologies in judicial activity through training of judges and court staff in the conditions of digitalization of modern society, improving computer literacy of people who use court services; overcome other problems that may affect the availability and quality of justice. It is not excluded that in the near future specialists of mixed competencies will be required, namely: a lawyer with knowledge of programming. The professional community should be ready to introduction of digital achievements. It seems relevant to use computer programs based on artificial intelligence in the analysis of situations, assessment of possible solutions, determination of possible options for the application of legislation in cases of indisputable facts for the development of draft decisions in the consideration of "standard" cases by judges, for example, civil cases in summary and ordered procedures, when cases of indisputable nature are considered, without holding court sessions, based on documents submitted to the court.

\section{REFERENCES}

[1] The Decree of the President of the Russian Federation of October 10, 2019 № 490 "On the development of artificial intelligence in the Russian Federation". 2019. Retrieved from http://publication.pravo.gov.ru/Document/View/000120 1910110003 ? index $=0$ \&rangeSize $=1$

[2] V.A. Laptev, N.I. Solovyanenko, "Judicial cloud": legal issues of data structuring and protection, Aktualnye problemy rossijskogo prava 6 (2019) 195204. DOI: https://doi.org/10.17803/19941471.2019.103.6.195-204

[3] L.A. Voskobitova, Criminal Justice and Digital Technology: Compatibility Issue, Lex Russica 5 (2019) 91-104. DOI: https://doi.org/10.17803/17295920.2019.150.5.091-104
Replace Lawyers?, Zakon 11 (2017) 110-123.

[5] M.N. Zarubina, A.A. Pavlov, On procedural realities and potential possibilities of the use of electronic evidence in civil procedure, Vestnik grazhdanskogo processa 1 (2019) 205-222. DOI: https://doi.org/10.24031/2226-0781-2019-9-1-205-222

[6] O.I. Andreeva, V.V. Ivanov, A.Yu. Nesterov, T.V. Trubnikova, Facial Recognition Technologies in Criminal Proceedings: Problems of Grounds for the Legal Regulation of Using Artificial Intelligence, Tomsk State University Journal 449 (2019) 201-212. DOI: https://doi.org/10.17223/15617793/449/25

[7] E.A. Borisova, Audio and Video Record Keeping: Advantages and Disadvantages, Vestnik grazhdanskogo processa 1 (2018) 39-50. DOI: https://doi.org/10.24031/2226-0781-2018-8-1-39-50

[8] A.V. Malko, M.A. Kostenko, Digital technologies in the judicial system: problems of implementation, Rossijskaa usticia 2 (2019) 52-54.

[9] O.A. Kapustin, The Impact of the Use of Information Technology in Federal General Jurisdiction Courts on the Prospects of Changes in the Territorial Judicial Structure, Administrator suda 2 (2019) 3-8.

[10] Momotov said why artificial intelligence will never replace a judge. 2019. Retrieved from https://pravo.ru/news/210547/. 30 January 2020.

[11] O.V. Gritsay, E.I. Gubina, Digitalization as a way of optimizing the mechanism of protection of civil rights in the field of civil jurisdiction, Iuridicheskii vestnik Samarskogo universiteta 5(2) (2019) 64-68. DOI: https://doi.org/10.18287/2542-047X-2019-5-2-6468

[12] R.F. Zakirov, The Use of Modern IT-Technologies as a Mean to Achieve the Basic Tasks of Legal Proceedings, Vestnik grazhdanskogo processa 1 (2018) 211-219. DOI: https://doi.org/10.24031/2226- 07812018-8-1-211-219

[13] I.P. Popova, Automation of the Criminal Procedure: Evil or Blessing for the Society?, Mirovoj sudia 11 (2019) 3-14

[14] M.I. Kleandrov, Whether Judge Be Robot?, Rossijskoe pravosudie 6 (2018) 15-25. DOI: https://doi.org/10.17238/issn2072-909X.2018.6.15-25 
[15] K.L. Branovitskiy, Correlation of the Notions of Quality and Digitalization of Justice, Arbitrazhnyj i grazhdanskij process 7 (2019) 3-7.

[16] Judicial Department under the Supreme Court of the Russian Federation. 2019. The data of judicial statistics. $\quad$ Retrieved from http://www.cdep.ru/index.php?id=79\&item=5083. 30 January 2020.

[17] A.V. Neznamov, On Application of Artificial Intelligence Technologies in Justice: A Terminological Aspect, Arbitrazhnyj i grazhdanskij process 10 (2019) 14-18.

[18] I.I. Chernykh, Legal Forecasting in the Field of Civil Proceedings in the Context of Development of Information Technologies, Aktualnye problem rossijskogo prava 6 (2019) 58-72. DOI: https://doi.org/10.17803/1994-1471.2019.103.6.058-

072

[19] K.A. Amiyants, K.V. Chemerinsky, The use of artificial intelligence in the modern judicial system and human rights, Mezhdunarodnyj zhurnal gumanitarnyh i estestvennyh nauk 11-3(38) (2019) 49-52. DOI: https://doi.org/10.24411/2500-1000-2019-11811

[20] I.V. Rostovschikov, I.A. Aleshkova, O.K. Molokaeva, Judiciary Power and Information Society: New Approaches and Opportunities, in: E.G. Popkova (Ed.), Ubiquitous Computing and the Internet of Things: Prerequisites for the Development of ICT, Studies in Computational Intelligence, vol. 826, Springer, Cham, 2019, pp. 185-193. DOI: https://doi.org/10.1007/978-3-030-13397-9_22 